\title{
The Effect Of Audit Findings And Recommendation Follow Ups Of BPK- Ri's Evaluation On Local Government's Performance In Districts/Cities East Java Province
}

\author{
Garsuarani Octavianti Ningsih ${ }^{1}$, Sugiharti Binastuti ${ }^{2}$ \\ ${ }^{1,2}$ Faculty EconomyGunadarma University, Indonesia \\ ${ }^{*}$ Corresponding author: \\ Email: Vinty1996@gmail.com
}

\begin{abstract}
.
Audit findings and recommendation follow ups are the result of evaluation conducted by BPK. This research aims to investigate the indirect effect of audit findings and recommendation follow ups from the evaluation done by $B P K-R I$ towards the performance of local governments in East Java Province through financial accountability which will be measured by audit opinions from 2013 to 2018. The data used is taken from The Audit Board of The Republic of Indonesia both directly and through website. The data is being tested using STATA. The test result of financial accountability model shows that audit findings on weakness of internal control system, standard deviation, follow up quantity, and recommendation value from the evaluation is indeed influential towards financial accountability. However, for audit findings on non-compliance to regulations in fact does not affect the financial accountability. Furthermore, predicted opinion value is used to test indirect effect which is being connected to performance. The result shows that audit findings and recommendation follow ups from the evaluation do affect indirectly towards the performance of local governments in East Java Province.
\end{abstract}

Key words: Financial accountability, local government's performance, audit opinions, audit findings, recommendation follow ups.

\section{INTRODUCTION}

Ever since the shifting of era from the new order to revolution in 1988 as the impact of economic, political, law, and social downturn at the end of 1997, the event has caused the occurrence of constitutional problems related to the centralized governance in the new order era which also triggered a very large gap between the development in regional areas with those in big cities. This issue then became the driving force for the society to demand their own authority to be able to organize and take care of their region, which later named as regional autonomy in Indonesia. Regional government runs their duty to increase the prosperity of their citizen by providing public services, however, the issue on managing the regional financial became very urgent due to the use of public source of funding. Therefore, regional government needs to manage their financial in a way that is transparent, accountable, and appropriate with the regulation. To ensure this, it needs to be evaluated by the authorities, which in this case is The Audit Board of The Republic of Indonesia (BPK).

The evaluation done by BPK will generate audit findings, recommendation, and audit opinions. Audit findings usually consists of the weakness in internal control system and noncompliance to regulations. Moreover, the evaluation of financial statements also creates recommendation. Recommendation is suggestions made by the auditor directed to officials or those who are in charge to perform a correction. Remedial action which can be done by the local government is by doing asset rescue, submission of money to the local/state cash, and administrative action. Audit opinion is a professional statement which contains a conclusion expressed by the auditor concerning the level of fairness in the information provided in financial statements. The type of audit opinion given by BPK is based on the suitability with the Government Accounting Standards (SAP), adequate disclosures, compliance towards regulations, as well as the effectiveness of internal control system. A good audit opinion reflects a fair financial statements and reliable information. Moreover, local financial management has also been done better which is shown in little audit findings and more 
recommendation which is being followed up by the local governments. According to that statement, this research aims to investigate the indirect effect of audit findings towards local government's performance through financial accountability which is reflected from the audit opinions received by local government.

\section{LITERATURE REVIEW}

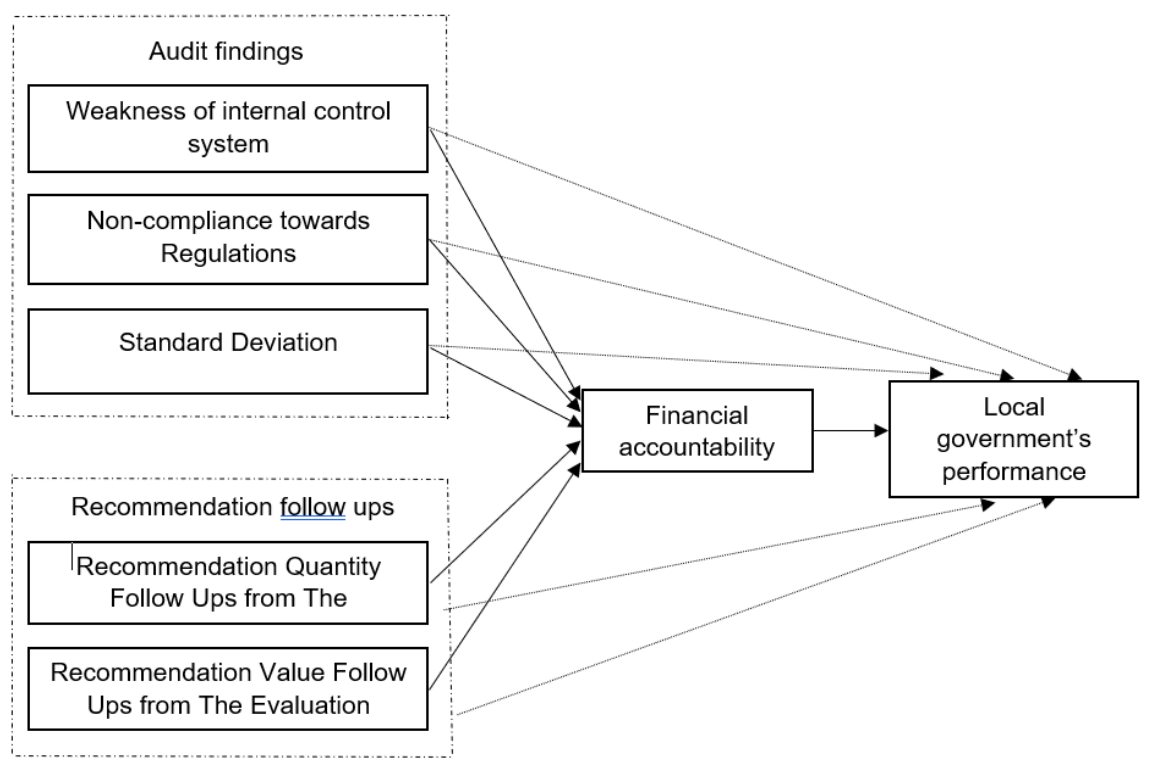

Fig 1. Research Model

\section{Hypothesis:}

H1: Audit findings in form of the total number of weakness in internal control system which affects the financial accountability.

$\mathrm{H} 2$ : Audit findings in form of the total number of non-compliances towards regulations affects the financial accountability.

H3: Deviation level affects the financial accountability.

H4: Follow up the total number of recommendations on the evaluation of financial accountability.

H5: Follow up the recommendation value on evaluation results affects the financial accountability.

H6: Audit findings and recommendation follow ups on the evaluation indirectly affects towards the local government's performance.

\section{METHOD}

\section{Research Object and Population}

There are two objects which became the focus of this research, first is financial accountability issued by The Audit Board of The Republic of Indonesia (BPK RI), and second is local government's performance in districts/cities in East Java province. There are a total of 29 districts and 9 cities in East Java Province. The population of this research is the entire local governments in East Java Province from 2011 to 2015 . The method used to take sample is by using the purposive sampling method.

\section{Research Population and Sample}

The population in this research is the entire local governments in districts/cities in East Java Province from 2011 to 2015. The method used to take sample in this research is by using the purposive sampling method. The criteria of sample used in this research is as follow:

1. Local governments in districts/cities in East Java Province which own performance appraisal data of EKPPD (performance evaluation in running local governance) from 2011 to 2015. 
2. Local governments in districts/cities which own data on audit opinion as a proxy of financial accountability, audit findings, and recommendation follow ups of BPK's evaluation summarized in IHPS (summary of semester evaluation report) BPK RI.

3. Local governments in districts/cities which composed LKPD (Local government financial statements) from 2011 to 2015 and has been audited by BPK in form of LHP-LKPD (evaluation reports on local government financial statements).

\section{Analysis Technique}

\section{Descriptive Statistics Analysis}

Descriptive statistics analysis is used to observe the fairness and features in data being researched. In this kind of analysis, the instrument being used are maximum and minimum value, mean, as well as standard deviation.

\section{Financial Accountability Model Testing}

Model testing on financial accountability used the binary logistic regression test (panel data) due to the use of dummy proxy as a dependent variable in this research and also using the marginal effect test to interpret the data. Model testing is conducted by using the STATA 12 software. Then, various tests are done in order to analyze the model of financial accountability such as goodness of fit test, model accuracy test, Wald test, likelihood ratio test, and Pseudo R2.

\section{Performance Model Testing}

The data used in this research is in the form of panel data. In analyzing panel data model, there are three approaches: pooled last square, fixed effect, and random effect. To determine which approach is the most suitable for this research, there are several testing levels which need to be conducted, which are Chow test, LM test, and Hausman test.

\section{ANALYSIS AND FINDINGS}

\section{A. Descriptive Analysis Result}

1. Descriptive Analysis on Financial Accountability Model Sample

Descriptive statistic on table 4.1 shows the value of financial accountability statistics. Descriptive statistics on table 4.1 is the value prior to being winsorized on the outlier data, this is done for research purposes. The descriptive statistics data after winsorize can be seen in appendix 1 . Research variable which contains outlier data is the standard deviation (Nilreg).

Table 4.1 Descriptive Statistics of Financial Accountability Model Sample

\begin{tabular}{|l|c|c|c|r|r|}
\hline Variable & Obs & Mean & Std. Dev. & \multicolumn{1}{|c|}{ Min } & \multicolumn{1}{c|}{ Max } \\
\hline Opini & 183 & 0.9180328 & 0.275067 & 0 & 1 \\
\hline Ispi & 183 & 6.295082 & 3.061697 & 1 & 18 \\
\hline Ireg & 183 & 7.491803 & 3.47814 & 1 & 22 \\
\hline Nreg & 183 & 0.0041361 & 0.012403 & 0.0000121 & 0.092116 \\
\hline Irek & 183 & 0.6428913 & 0.293901 & 0.0196 & 1 \\
\hline Nrek & 183 & 0.7710881 & 0.294295 & 0.0027359 & 1 \\
\hline
\end{tabular}

n-observation $=183$

Notes: JMLSPI $=$ Audit findings on weakness of internal control system; JMLREG $=$ Audit findings on non-compliance to regulations; NILREG $=$ Standard deviation; JMLREKOMEN $=\%$ of total followed up recommendations; NILREKOMEN $=\%$ of followed up recommendation value.

Table 4.2 Frequency of Dummy Variable

\begin{tabular}{|c|c|c|}
\hline Variabel & Frekuensi & Persentase \\
\hline OPINI & & \\
\hline 1 (WTP, WTP-DPP, WDP) & 168 & $92 \%$ \\
\hline 0 (Bukan WTP, WTP-DPP, WDP) & 15 & $8 \%$ \\
\hline
\end{tabular}


Table 4.2 shows the frequency of opinion for the period of 2011-2015. According to the research sample, there are 168 or approximately $92 \%$ of local governments received Unqualified Opinion (WTP), Modified Unqualified Opinion (WTP-DPP), as well as Qualified Opinion (WDP). Wherein there are as many as 15 or approximately $8 \%$ of local governments that received Adverse Opinion (TW) and Disclaimer Opinion (TMP).

\section{Descriptive Analysis of Performance Model Sample}

Table 4.3 is a descriptive statistics of research variable sample used in performance model. Descriptive statistic shown in table 4.3 is the ones prior to being winsorized. The data after winsorize can be seen in appendix 1. Research variable which contains outlier data in this model is the independence level of local governments (PAD).

Table 4.3 Descriptive Statistics of Performance Model Sample

\begin{tabular}{|l|l|l|r|r|r|}
\hline Variable & Obs & \multicolumn{1}{c|}{ Mean } & \multicolumn{1}{c|}{ Std. Dev. } & \multicolumn{1}{c|}{ Min } & \multicolumn{1}{c|}{ Max } \\
\hline Knerja & 183 & 3,0860774 & 0,182009 & 2,6413 & 3,5472 \\
\hline AK & 183 & 0.9180328 & 0.200074 & 0.0003334 & 0,999966 \\
\hline
\end{tabular}

Notes: KINERJA= Local governments performance score; AK= Financial Accountability.

Performance variable on the local governments is measured by using the EKPPD (performance evaluation in running local governance) according to the local government administration reports (LPPD) in 2011-2015. Performance score is divided into 4 categories, 0-1 for low performance, 1-2 for medium performance, 2-3 for high performance, 3-4 for excellent performance. The result of descriptive statistics shows that the average score for local governments performance in districts/cities for the time period of 2011 to 2015 is 2,3919 which indicates that the number falls within a high performance category.

Local government which acquired the highest score is Sidoarjo District in 2015 with the point of 3,5472, wherein the one with the lowest score is Probolinggo District in 2013 with the point of 2,641 .

3. Analysis of Financial Accountability Model

Table 4.4 Regression Test Result on Financial Accountability Model

\begin{tabular}{|c|c|c|c|}
\hline \multicolumn{4}{|c|}{ OPINI } \\
\hline Variabel & Hipotesis & Koefisien & P stat \\
\hline JMLSPI & H1 & $-0,3726$ & 0,005 \\
\hline JMLREG & $\mathrm{H} 2$ & 0,2715 & 0,057 \\
\hline NILREG & $\mathrm{H3}$ & $-80,2801$ & 0,017 \\
\hline JMLREKOMEN & H4 & $-5,7181$ & 0,044 \\
\hline NILREKOMEN & H5 & 4,4719 & 0,001 \\
\hline STATUS & & 1,0637 & 0,319 \\
\hline PENDUDUK & & 0,8744 & 0,646 \\
\hline Pseudo R-squared & 0,5476 & & \\
\hline LR Statistik & 56,83 & & \\
\hline Prob (LR Statistik) & 0,000 & & \\
\hline n-Observation & 193 & & \\
\hline
\end{tabular}

Notes: OPINI=audit opinion; JMLSPI= Audit finding on weakness of internal control system; JMLREG $=$ Audit finding on non-compliance to regulations; NILREG $=$ Standard deviation; JMLREKOMEN= Recommendation quantity follow ups from evaluation; NILREKOMEN= Recommendation value follow ups from evaluation; STATUS= Type of local government; PENDUDUK= Population of local governments.

Table 4.5 Marginal Effect Test Result 


\begin{tabular}{lc}
\hline \multicolumn{1}{c}{ Variabel } & $d y / d x$ \\
\hline JMLSPI & $-0,1321$ \\
JMLREG & 0.0096 \\
NILREG & $-2,8449$ \\
JMLREKOMEN & $-0,2026$ \\
NILREKOMEN & 0,1585 \\
STATUS & 0,0309 \\
PENDUDUK & 0,0377 \\
\hline
\end{tabular}

Notes: JMLSPI $=$ Audit finding on weakness of internal control system; JMLREG= Audit finding on non-compliance to regulations; NILREG $=$ Standard deviation; JMLREKOMEN $=$ Recommendation quantity follow ups from evaluation; NILREKOMEN= Recommendation value follow ups from evaluation; STATUS = Type of local governments; PENDUDUK= Population of local governments.

\section{A. The Effect of Audit Findings on The Weakness of Internal Control System (H1)}

According to the binary logistic regression test result which is shown in table 4.3 , it can be seen that the audit findings on the weakness of internal control system appears as negative towards audit opinions. This negative effect is shown by coefficient value of $-0,3726$ and $p$-stat of 0,005 .

\section{B. The Effect of Audit Findings on Non-compliance towards Regulations (H2)}

According to the data in table 4.3, the quantity of audit findings on non-compliance towards regulations is in fact influential to audit opinions with coefficient value of 0,2715 and p-stat of 0,057 .

\section{The Effect of Standard Deviation (H3)}

According to the data in table 4.4, the standard deviation in this case, audit findings on the weakness of internal control towards non-compliance to the regulations is affected with negative value towards audit opinions which is shown by the coefficient value of $-80,2801$ as well as p-stat value of 0,017 .

\section{The Effect of Recommendation Quantity Follow Ups from The Evaluation (H4)}

According to the data in table 4.4, the result of hypothesis test shows that the quantity of recommendations being followed up by the local governments affects negatively towards audit opinions with certainty level of $95 \%$ which is shown by the coefficient value of $-5,7181$ and $p$-stat of 0,044 .

\section{E. The Effect of Recommendation Value Follow Ups from The Evaluation (H5)}

The data in table 4.4 shows that recommendation value that is being followed up by the local government is influential towards audit opinions with the coefficient value of 4,4719 and p-stat of 0,001 . This means that the more recommendation value being followed up by the local governments, the bigger the opportunity to receive a better audit opinions in the future.

\section{Performance Model Analysis}

Table 4.6 Regression Test Result on Performance Model

\begin{tabular}{|c|c|c|c|}
\hline \multicolumn{4}{|c|}{ KINERJA } \\
\hline Variabel & Hipotesis & Koefisien & Pstat \\
\hline PROPINI & $H G$ & 0,2957 & 0,003 \\
\hline TA & & 0,0402 & 0,037 \\
\hline PAD & & 0,0763 & 0,309 \\
\hline DAU & & $-0,1544$ & 0,291 \\
\hline Wald chiz & 14,79 & & \\
\hline Prob $>$ chiz & 0,005 & & \\
\hline n-Observation & 183 & & \\
\hline
\end{tabular}

Notes: $\mathrm{KINERJA}=$ Performance score of local government; $\mathrm{PROPINI}=$ Predicted opinion value; $\mathrm{TA}=$ The size of local governments; $\mathrm{PAD}=$ Independence level of local governments; $\mathrm{DAU}=$ Dependency level local governments. 
Table 4.7 The Calculation of Indirect Effect of Audit Findings and TLRHP towards Local Governments

Performance

\begin{tabular}{lcclcc}
\hline & Koefisien & Pstat & & Koefisien & Pstat \\
\hline JMLSPI & $-0,3726$ & 0,005 & PROPINI & $-0,2957$ & 0,003 \\
JMLREG & 0,2715 & 0,057 & PROPINI & $-0,2957$ & 0,003 \\
NILREG & $-80,2801$ & 0,017 & PROPINI & $-0,2957$ & 0,003 \\
JMLREKOMEN & $-5,7181$ & 0,044 & PROPINI & $-0,2957$ & 0,003 \\
NILREKOMEN & 4,4719 & 0,001 & PROPINI & $-0,2957$ & 0,003 \\
\hline
\end{tabular}

\section{F. Indirect Effect of Audit Findings and TLRHP towards Local Governments Performance (H6)}

Predicted opinion value is used to observe the indirect effect of audit findings and recommendation follow ups towards local governments' performance through financial accountability. According to regression test result, it can be seen that predicted opinion value has a positive relation with the performance of local governments. This is shown from the coefficient value in the regression test result of $-0,2957$ and $\mathrm{p}$-stat of 0,003 . This result shows that there is indeed indirect effect from audit findings and recommendation follow ups towards the performance of local governments.

\section{CONCLUSION AND RECOMMENDATIONS Conclusion}

This research aims to find out whether there is any effect between audit findings and recommendation follow ups towards the accountability of local government's performance. This research used the total sample of 183 local governments from 190 districts/cities samples in the period of 2011-2015.

1. The research found that audit findings on the weakness of internal control system does affect the financial accountability.

2. The research found that audit findings on non-compliance to regulations does not affect the financial accountability.

3. The research found that audit findings on standard deviation does affect the financial accountability.

4. The research found that the quantity of recommendation does affect the financial accountability.

5. The research found that recommendation value does affect the financial accountability.

6. The research found that audit findings and recommendation follow ups do indirectly affect the financial performance of local governments in the form of opinion or predicted value.

\section{Recommendations}

There are a number of limitations in this research, some of them are as follow:

1. Data sample of this research only covers East Java Province, therefore it seems needed to conduct further research in a wider range.

2. This research only investigates in the level of local government districts and cities. Further research is suggested to be able to investigate province level.

3. This research only used a secondary data. Further research is suggested to be able to use a primary data such as from a direct interview with the parties who are closely involved in the process of financial assessment and setting the score for local government's performance in order to support strengthen research findings. 
4. Further research can utilize other proxy which will reflect a better accountability and performance in portraying a phenomenon.

\section{REFERENCES}

[1] Adzani,A.H., \& Martani, D.(2014). Analisis pengaruh kesejahteraan masyarakat, faktor politik, dan hasil pemeriksaan audit BPK terhadap opini audit LKPD tahun 2009-2011. Simposium Nasional Akuntansi.

[2] Arens, et al.(2009). Auditing and assurance service: an integrates approach and Indonesia adaption. New York: Pearson.

[3] Badan Pemeriksa Keuangan.(2010). Peraturan Badan Pemeriksa Keuangan Nomor 2 Tahun 2010 tentang Pemantauan Tindak Lanjut Hasil Pemeriksaan. Jakarta: Badan Pemeriksa Keuangan RI.

[4] Badan Pemeriksa Keuangan.(2011). Ikhtisar Hasil Pemeriksaan Semester I 2011.Jakarta: Badan Pemeriksa Keuangan RI.

[5] Badan Pemeriksa Keuangan.(2011). Ikhtisar Hasil Pemeriksaan Semester II 2011.Jakarta: Badan Pemeriksa Keuangan RI.

[6] Badan Pemeriksa Keuangan.(2012). Ikhtisar Hasil Pemeriksaan Semester I 2012.Jakarta: Badan Pemeriksa Keuangan RI.

[7] Badan Pemeriksa Keuangan.(2012). Ikhtisar Hasil Pemeriksaan Semester II 2012. Jakarta: Badan Pemeriksa Keuangan RI.

[8] Badan Pemeriksa Keuangan.(2013). Ikhtisar Hasil Pemeriksaan Semester I 2013. Jakarta: Badan Pemeriksa Keuangan RI.

[9] Badan Pemeriksa Keuangan.(2013). Ikhtisar Hasil Pemeriksaan Semester II 2013. Jakarta: Badan Pemeriksa Keuangan RI.

[10] Badan Pemeriksa Keuangan.(2014). Ikhtisar Hasil Pemeriksaan Semester I 2014. Jakarta: Badan Pemeriksa Keuangan RI.

[11] Badan Pemeriksa Keuangan.(2014). Ikhtisar Hasil Pemeriksaan Semester II 2014. Jakarta: Badan Pemeriksa Keuangan RI.

[12] Badan Pemeriksa Keuangan.(2015). Ikhtisar Hasil Pemeriksaan Semester I 2015. Jakarta: Badan Pemeriksa Keuangan RI.

[13] Badan Pemeriksa Keuangan.(2015). Ikhtisar Hasil Pemeriksaan Semester II 2015. Jakarta: Badan Pemeriksa Keuangan RI.

[14] Bernardin, H. J., \& Russel, J.E.A.(2000). Human Resource Management.Singapore: McGraw Hill,I. 
